\title{
ОСОБЛИВОСТІ ВИДІЛЕННЯ ОБ'ЄКТІВ ПУБЛІЧНОЇ ФІНАНСОВОї ДІЯЛЬНОСТІ ФІНАНСОВИХ УСТАНОВ УКРАЇНИ
}

Бернацький I. В.

У науковій статmі досліджено ключові об'єкти публічної фінансової діяльності з урахуванням специфіки участі фінансових установ України в системі публічних фінансових потоків.

Встановлено, що сучасні публічні фінансові відносини базуються на кругообігу фінансових ресурсів в системі акумулювання, розподілу, перерозподілу та використання. При цьому невід'ємним елементом забезпечення постійності, стабільності та ефективності цього руху фінансових коштів є їхня циркуляція через фінансові установи України.

3 фінансово-правової позиції визначено, що одним із важливих об'єктів регулювання публічної фінансової діяльності фінансових установ України є державний та місцеві бюджети, оскільки в Україні зауважено достатньо високий рівень централізації державних фінансів.

Проведено аналіз динаміки та структуру міжнародних резервів України як об'єкту регулювання публічних фінансових відносин і встановлено поступове відновлення рівня чистих міжнародних резервів України з 2015 року, що позитивно впливає на рівень фінансової безпеки держави та вказує на покращення монетарної стратегії державних регуляторів у сфері регулювання публічних фінансових відносин. У той же час зростання відношення резервів до короткострокового зовнішнього боргового портфеля демонструвало хвилеподібні зростаючі тренди, що з позиціі фінансів може свідчити про непослідовність боргової політики та значний вплив макроекономічних шоків на ефективність публічної фінансової діяльності фінансових установ України.

Автор визначив, що в залежності від суб'єкта розгляду до об'єктів публічної фінансової діяльності фінансових установ України належать фінансові потоки грошових коштів, а також фінансові операції, які опосередковують такі потоки, фінансова звітність, інші форми корпоративного розкриття інформачії за напрямами діяльності, джерела залучення та напрямки розміщення фінансових ресурсів. Визначальним при цьому є дотримання принципів транспарентності інформації щодо проведення публічної фінансової діяльності фінансових установ, їхньої економічної ефективності, доцільності, раціональності та якості управління наявними фінансовими ресур-

(c) Бернацький І. В., 2020 сами. Це створює передумови для синергії правової та економічної науки в межах реалізації нормативної фінансової діяльності на реальних фінансових ринках.

Ключові слова: публічні фінанси, об'єкт, регулювання, фінансова установа, діяльність, клієнт, правовідносини.

Bernatskyi I. V. Peculiarities of allocation of objects of public financial activity of financial institutions of Ukraine

The aim of this article is to present the key objects of public financial activity, taking into account the specifics of the participation of financial institutions of Ukraine in the system of public financial flows.

It is established that modern public financial relations are based on the circulation of financial resources in the system of accumulation, distribution, redistribution and use, while an integral element of ensuring the stability, stability and efficiency of this hand is their circulation through financial institutions of Ukraine.

From the financial and legal point of view, it is determined that one of the key objects of regulation of public financial activities of financial institutions of Ukraine is the state and local budgets, as in Ukraine there is a fairly high level of centralization of public finances.

After analyzing the dynamics and structure of Ukraine's international reserves as an object of regulation of public financial relations, a gradual recovery of Ukraine's net international reserves since 2015 has been established, which has a positive effect on the state's financial security and indicates an improvement in monetary policy. relations. At the same time, the growing ratio of reserves to short-term external debt portfolio showed wave-like upward trends, which from the financial point of view may indicate inconsistency of debt policy and significant impact of macroeconomic shocks on public financial performance of financial institutions in Ukraine.

The author determined that, depending on the subject of consideration, the objects of public financial activity of financial institutions of Ukraine include financial cash flows, as well as financial transactions that mediate such flows, financial statements, other forms of corporate disclosure of activities, sources attraction and directions of allocation of financial resources. Determining the principles of transparency of information on public financial activities of financial institutions, their 
economic efficiency, feasibility, rationality and quality of management of available financial resources, which creates conditions for synergy of legal and economic science in the implementation of regulatory financial activities in real financial markets.

Key words: public finance, object, regulation, financial institution, activity, client, legal relations.

Постановка проблеми та іï актуальність. Актуальність роботи визначається тим, що в сучасній правовій системі все більшого розвитку набувають правовідносини фінансових установ під час участі у процесі формування, розподілу та використання публічних фінансових ресурсів. Дослідження теоретико-методичних основ та правової природи публічної фінансової діяльності фінансових установ України дозволяє розглянути об'єкти такої публічної фінансової діяльності.

Аналіз останніх досліджень і публікацій. Питання правовідносин та участі фінансових установ України в межах публічної фінансової діяльності дослідило багато вітчизняних науковців, зокрема Д.О. Білінський, І.М. Бондаренко, О.О. Головашевич, Д.О. Білінський, О.О. Дмитрик, Л. К. Воронова, М. П. Кучерявенко, Н.Ю. Пришва, О.М. Бандурка, Ю.М. Жорнокуй та інші [7-10].

Метою статті $\epsilon$ узагальнення особливостей виділення об'єктів публічної фінансової діяльності фінансових установ України в межах регулювання публічних фінансових потоків.

Виклад основного матеріалу. Базовим нормативним актом, що визначає сферу фінансових правовідносин фінансових установ та клієнтів (фізичних та юридичних осіб), $\epsilon$ Закон України «Про фінансові послуги та державне регулювання ринків фінансових послуг» [1], що визначає загальні правові засади надання фінансової послуги з боку фінансової установи, регулювання та нагляд за діяльністю фінансових установ в Україні, зокрема щодо проведення ними публічних фінансових операцій. За цим законом базовою одиницею розгляду, на нашу думку, $\epsilon$ фінансова послуга, яка трактується як операція з фінансовими активами, проведена фінансовою установою в економічних інтересах третіх осіб за власний рахунок, залучений пакет фінансових ресурсів або за рахунок бенефіціарів такої операції. Водночас для фінансової установи метою проведення фінансової операції $\epsilon$ отримання прибутку (максимізація доданої економічної корисності) або збереження реальної вартості фінансових активів (мінімізації збитків щодо втрати доданої економічної корисності). Тобто з юридичного боку можна вважати за об'єкт публічної фінансової діяльності фінансових установ України всі фінансові операції, які опосередковують рух публічних (державних, муніципальних та інших) фінансів. Тобто селективно загальний обсяг сфери фінансових операцій значно вищий за поле публічних фінансових операцій, що проводяться через фінансові установи України, навіть з урахуванням значного обсягу централізації фінансових потоків у межах фінансової системи України.

3 огляду на це, актуальним $є$ розгляд об'єктів публічної фінансової діяльності фінансових установ України в контексті бюджетного регулювання на основі Бюджетного кодексу України [2]. Цей нормативно-правовий документ регулює відносини, які опосередковуються публічними фінансами щодо формування та використання бюджетних коштів на державному та місцевому рівнях. Оскільки в межах трактування публічної фінансової діяльності встановлено, що це діяльність здебільшого уповноважених державних органів та органів місцевого самоврядування щодо формування, розподілу, перерозподілу та використання тієї частини валового внутрішнього продукту, яка була акумульована в межах податкової та неподаткової діяльності з метою виконання державою та місцевими органами власних та делегованих функцій, то фінансові установи України виступають здебільшого посередниками в межах руху потоків публічних фінансів. 3 позиції об'єкта публічної фінансової діяльності в бюджетній сфері можна розглядати поняття «платіж», який, за Бюджетним кодексом України, $\epsilon$ формою виконання певного зобов'язання (боргового, бюджетного, податкового або гарантійного), що виникло унаслідок певних операцій у поточному чи будь-якому попередньому бюджетному періоді (зазвичай бюджетний період ототожнюють з календарним роком). Отже, фінансова установа України при проведенні платежів, які мають за матеріальну основу кошти державного або місцевого бюджету, дотична до публічних фінансових потоків і саме такі платежі будуть розглядатися як об'єкт регулювання публічної фінансової діяльності фінансових установ України.

3 огляду на сучасну специфіку та динаміку активності фінансових установ України щодо бюджетних потоків та публічних фінансових активів загалом, найбільшу частку об'єкта з юридичної позиції може складати державний борг як форма залучення державою коштів на внутрішньому та зовнішньому ринках для покриття фінансового дефіциту бюджету та фінансування певних бюджетних платежів. 3 економічної 
позиції в межах реалізації публічної фінансової діяльності держава може отримати ситуацію, коли сукупні акумульовані державні доходи будуть меншими за обсяг сукупних планових державних бюджетних витрат. 3 огляду на специфіку України, таке фінансово-економічне явище має практичну прикладну системну реалізацію майже щороку. У цьому випадку держава як важливий суб'єкт бюджетного управління через відповідні фінансові уповноважені інституції звертається на фінансовий ринок за додатковими фінансовими ресурсами, які беруться у борг на принципах повернення, строковості, платності, гарантованості, тобто з юридичного боку $\epsilon$ форма реалізації державних кредитних відносин. 3 огляду на слабку розвиненість фінансової інфраструктури в Україні, відсутність дозволу на використання ресурсів альтернативних фінансових активів (наприклад, криптовалют), низький рівень довіри населення до державних гарантій, значні початкові фінансові внески, зазвичай суб'єктами відносин із кредитування держави в коротко, середньо та довгостроковому періоді з урахуванням надмірного рівня ліквідності банківської системи України в 2019-2020 роках виступають саме фінансові установи, зокрема банки (як для власних фінансових інтересів, так і щодо операцій для клієнтів банків), інші небанківські фінансові установи, а також нерезиденти. Отже, на рівні держави як об'єкта публічної фінансової діяльності за умови участі фінансових установ в його формуванні та покриті виступає державний борг України, який зазвичай опосередковується завдяки використанню інструментарію облігацій внутрішнього державного боргу (далі - ОВДП).
Якщо розглядати облігації внутрішнього державного боргу як об'єкт публічної фінансової діяльності фінансових установ України, доцільно зазначити двоцентрове регулювання їхнього випуску, обслуговування та погашення як зі сторони Міністерства фінансів України, так і зі сторони Національного банку України [3-5]. Цей дуалізм правового регулювання випуску, обслуговування та погашення облігацій внутрішнього державного боргу як об'єкта публічної фінансової діяльності фінансових установ України, з одного боку, обумовлений різними повноваженнями та економічними цілями Міністерства фінансів України і Національного банку України, а 3 іншого - покликаний забезпечити баланс економічних інтересів бюджету та учасників боргового процесу. В межах постанови Кабінету міністрів України «Про випуски облігацій внутрішніх державних позик» від 31 січня 2001 р. № 80 законодавець робить поділ об'єктів публічної боргової діяльності на ОВДП короткострокового, середньострокового та довгострокового погашення залежно від терміну утримання таких державних боргових цінних паперів. В такому випадку фінансові установи України $\epsilon$ брокерами та дилерами на фінансовому ринку і опосередковують публічні фінансові потоки між Національним банком України, який проводить операції з випуску ОВДП, та фізичними і юридичними особами, які виступають покупцями ОВДП.

На рис. 1 проілюстровано валові та чисті міжнародні резерви України як об'єкта регулювання публічної фінансової діяльності за 2014-2020рр.

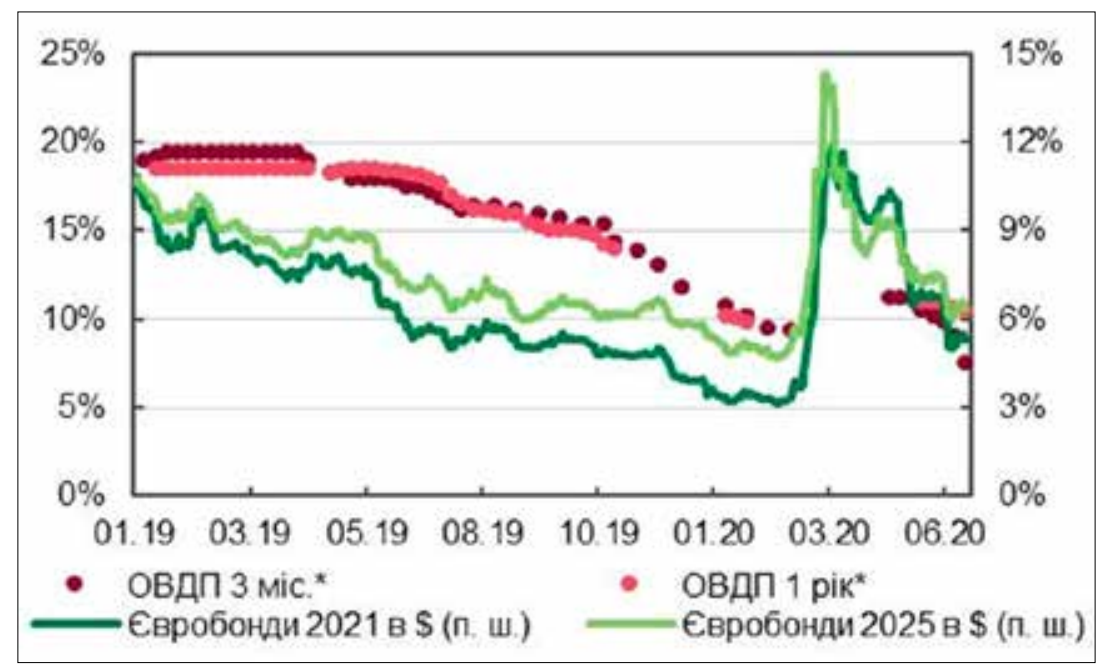

Рис. 1. Валові та чисті міжнародні резерви України як об'єкт регулювання публічної фінансової діяльності за 2014-2020 рр., млрд. дол. США

Джерело: [6] 


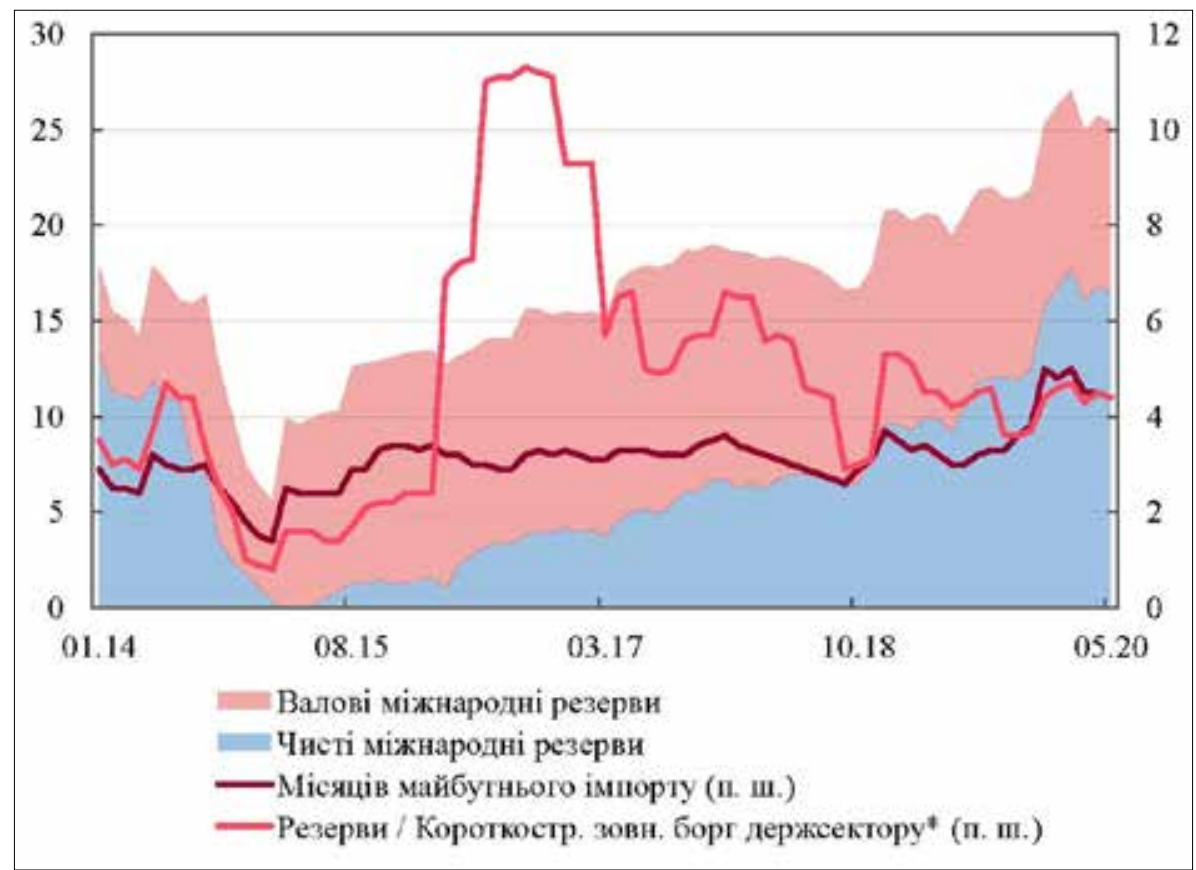

Рис. 2. Дохідність за борговими цінними паперами в Україні в 2019-2020 рр., \%

Джерело: [6]

Загалом бачимо зростання фінансового поля для регулювання публічної фінансової діяльності за 2014-2020 рр. в Україні, оскільки валові міжнародні резерви України з 01.01.2014 р. до 31.05.2020 р. зросли з 20,4 млрд. дол. США до 25,4 млрд. дол. США (навіть за умови девальвації національної валюти). Водночас чисті міжнародні резерви України мали тренд до росту з 15,2 млрд. дол. США до 16,5 млрд. дол. США, що вказує на активізацію процесу залучення коштів та їхнього подальшого резервування, зокрема з використанням фінансових установ України. Тоді ж у 2016-2017 рр. за наведеним графіком бачимо найбільш динамічне зростання відношення резервів до короткострокових кредитів за зовнішніми боргами державного сектору України, що вказує на потребу коригування державної боргової політики, щоб не допустити технічний та фактичний державний дефолт в Україні.

Водночас, якщо розглядати дохідність ОВДП як об'єкту публічної фінансової діяльності фінансових установ України, що наведено на рис. 2, слід зазначити з економічної позиції різкі підйоми в 1 кварталі 2020 p.

Наведена динаміка дохідності може бути зумовлена як об'єктивними економічними аспектами падіння рівня економічного інтересу важливих держателів державного боргу України (переважно фінансових установ та нерезидентів), так і можливим проведенням спекулятивних фінансових операцій. Це вказує на відсутність досконалого правового поля регулювання об'єктів публічної фінансової діяльності фінансових установ України.

Висновки. Отже, визначено, що залежно від суб'єкта розгляду до об'єктів публічної фінансової діяльності фінансових установ України відносяться фінансові потоки грошових коштів, а також фінансові операції, які опосередковують такі потоки, фінансова звітність, інші форми корпоративного розкриття інформації за напрямами діяльності, джерела залучення та напрями розміщення фінансових ресурсів. Визначальним при цьому $\epsilon$ дотримання принципів транспарентності інформації щодо проведення публічної фінансової діяльності фінансових установ, їхньої економічної ефективності, доцільності, раціональності та якості управління наявними фінансовими ресурсами. Це створює передумови для синергії правової та економічної науки в межах реалізації нормативної фінансової діяльності на реальних фінансових ринках.

\section{Література}

1. Про фінансові послуги та державне регулювання ринків фінансових послуг : Закон України від 12 липня 2001 р. № 2664-III / Верховна Рада України. URL: https: / /zakon.rada.gov.ua/laws/show/2664-14

2. Бюджетний кодекс України : Закон України від 8 липня 2010 р. № 2456-VI / Верховна Рада України. 2010. № 50-51. СТ. 572. 
3. Про затвердження нормативних документів з питань обігу облігацій внутрішньої державної позики на Українській фондовій біржі : Постанова Національного банку України від 31 грудня 1997 р. № 477. URL: https://zakon.rada.gov.ua/laws/show/va477500-97

4. Про внесення змін до Бюджетного кодексу України та деяких інших законодавчих актів України : Закон України від 7 липня 2011 р. № 3614-VI / Верховна Рада України. / Відомості Верховної Ради України. 2012. № 9. Ст.63.

5. Про випуски облігацій внутрішніх державних позик : Постанова Кабінету міністрів України від 31 січня 2001 р. № 80.

6. Офіційний сайт Національного Банку України. URL: https: //bank.gov.ua

7. Фінансове право : посіб. для підгот. до іспитів / Д. О. Білінський та ін. Харків : Право, 2018. 212 с.
8. Фінансове право : підручник / М.П. Кучерявенко та ін.; за ред. М.П. Кучерявенка. Харків : Право, 2013. 400 с.

9. Фінансове право України : навч. посіб. [для студ. вищ. навч. закл.] / Л. К. Воронова та ін. Київ : Прав. єдність, 2009. 485 с.

10. Фінансове право : підручник / Бандурка О. М. та ін., за заг. ред. О. П. Гетманець; МВС України, Харків. нац. ун-т внутр. справ. Харків. 2017. 392 c.

Бернацький I. В., аспірант кафедри фінансового права Iнституту права Київського національного університету імені Тараса Шевченка 